\title{
Development of Paving Blocks using Waste Materials
}

\author{
Nor Baizura Hamid, Siti Noraiza Ab Razak, Mardiha Mokhtar, Mohd Erwan Sanik, Masiri \\ Kaamin, Ahmad Hakimi Mat Nor, Mohd Zakwan Ramli
}

\begin{abstract}
Nowadays, the paving blocks that in the market are heavy and the price are costly. This study will introduce the lightweight paving blocks and more affordable because the waste materials such as tins, plastic and quarry dust are use in the development of the concrete paving blocks namely as Eco-Friendly Paving Block. Eco paving blocks will be compared to control paving blocks due to its durability and compressive strength. Based on the past research, tin and plastic are used as coarse aggregate while quarry dust will act as fine aggregate. The method and test for concrete work was conducted which is slump test, density test and compressive strength test. The result shows that Eco-Friendly Paving Block can be used at non-traffic area based on their compressive strength with the value of $13.3275 \mathrm{~N} / \mathrm{mm}^{2}$ compared to control paving block with value of $72.3845 \mathrm{~N} / \mathrm{mm}^{2}$. The uses of this waste material also can reduce the amount of environmental pollutants such as water and soil pollution.
\end{abstract}

Index Terms: Paving, tins and plastic, quarry dust, eco-friendly

\section{INTRODUCTION}

Concrete block paving has been widely used nowadays because of its diverse advantages. It is forms in rectangular shape accordance to bricks shape and now there are many various shapes of paving blocks. These blocks are a type of concrete with good in quality and durability due to the manufacturing and the right method of mixture. The concrete paving blocks also something interesting and versatile because of its great resilience, its strength in accommodate traffic flow, interesting aesthetic, and function, cost effective and do not need to be maintenance if the correct way installations from first phase [1].

Revised Manuscript Received on July 22, 2019.

Nor Baizura Hamid, Siti Noraiza Ab Razak, Mardiha Mokhtar, Mohd Erwan Sanik, Masiri Kaamin, Ahmad Hakimi Mat Nor,Mohd Zakwan Ramli
The material that use for paving blocks has been widely changed where there are many of paving blocks are added or replaced with the used materials or wastes materials to reduce environmental pollutions besides can improve its strength and also their mechanical properties. From the literature study, there are many researchers use waste materials as the aggregate and cement replacement to create paving blocks. The materials used are plastic, fly ash, bottom ash, tin, limestone dust, tiles, rubber, coconut fiber, glass and so on which these materials are available in cheaper price or free of charge.

However, there are several weaknesses in the common paving blocks which required high cost for its creation. In addition, the paving blocks that made from gravel with full quantities are heavy. Therefore, the purpose of this study was to review that waste materials such as tin and plastic and also quarry dust can be reuse as additives and replacement material in paving blocks. In addition, it is also intended to protect the environment from the accumulation of waste materials that can affect the ecosystem and environment especially to wildlife and humans. Objective of the study that wishes to be achieved is to produce paving blocks from tin, plastic also quarry dust and to identify the most economical cost of paving blocks. This studied also want to achieve the lighter paving blocks and prove their durability with using compression test.

To solve the problems and achieve the objectives, new paving blocks is produced with the use of waste materials that available in free of charge to reduce costs and reduce the percentage of used coarse gravel to $60 \%$ from the full percentage of coarse aggregate total which this rocks affects mass of paving blocks. The $40 \%$ of the used materials are used as coarse aggregate. The scope of these study are to test the durability of Eco-Friendly Paving Block that use waste materials (tin and plastic) as an admixture in coarse aggregate with coarse gravel and unused materials (quarry dust) which is replaced fine aggregate in concrete mixture and will be compared to control paving blocks. These materials are mixed with cement and water according to the ratio. The used materials are cut to the needed sizes. The 


\section{Development of Paving Blocks Using Waste Materials}

rectangular size of paving blocks will be produced using 12 moulds with size $50 \mathrm{~mm} \times 200 \mathrm{~mm} \times 100 \mathrm{~mm}$ and it is proposed to be used in the walkway or garden where the traffic load in that area are less. There are 12 paving blocks produced where 6 of it are control paving blocks and the balance is Eco-Friendly Paving Block. The test will be done when the paving block reaches the 7 and 14 days of their mature age and the result of Eco-Friendly Paving Block will be compared to the control paving blocks based on the test performed.

\section{LITERATURE REVIEW}

\section{A. Design and Classification of Paving Blocks}

Normally, Paving blocks are rectangular-shaped and it is almost like a brick. But now, there is a lot paving blocks variation [1]. According to the study in this paper, the classification for paving blocks are based on SNI 03-0691-1996 and Table I show the classification of the paving blocks based on their compressive strength.

Table I: Classification of paving blocks [2]

\begin{tabular}{|c|c|c|c|}
\hline \multirow[t]{2}{*}{ Grade } & \multirow[t]{2}{*}{ Classification } & \multicolumn{2}{|c|}{$\begin{array}{c}\text { Compressive strength } \\
\qquad\left(\mathrm{N} / \mathbf{m m}^{2}\right)\end{array}$} \\
\hline & & Average & Minimum \\
\hline $\mathrm{A}$ & Road & 40 & 35 \\
\hline $\mathrm{B}$ & Parking & 20 & 17 \\
\hline $\mathrm{C}$ & Walkway & 15 & 12.5 \\
\hline $\mathrm{D}$ & $\begin{array}{l}\text { Garden } \\
\text { playground }\end{array}$ & 10 & 8.5 \\
\hline
\end{tabular}

\section{B. Materials}

Water that used to mix concrete and curing process must be free from hazardous materials. Generally the minimum water/cement ratio that been used is 0.3 to 0.8 for hydration. Excess water in the concrete mixture can cause bonding between concrete less effective and there is formation of holes in concrete mixture [1]. Concrete mixture ratio is $1: 2: 4$ (cement: sand: stone fragments) with a water/cement ratio 0.60 [3]. The waste materials used are quarry dust which is a by-product of quarrying activities to be made as fine aggregate [4]. The quarry dust is used for production of hollow block and light concrete. Fig. 1 shows an example of quarry dust that been used [5].

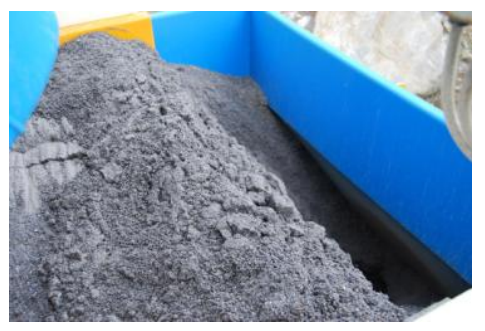

Fig. 1: Quarry dust [5]
Quarry dust can improve concrete mechanical properties such as elastic modulus and optimum compressive strength can be achieved with the use of the aggregate ratio of fine to coarse aggregate, 60:40 [6]. The cement are replaced by plastic waste to construct paving blocks at once to reduce the cost of paving blocks manufacture and it is used with different proportion with other materials such as coarse aggregate, Quarry dust and waste ceramics [7].Metal wastes such as cans of soft drinks are available from a variety of sources. Tin are cut to the desired size which is rectangular shapes and cleaned using water, then being dried then being scratch by the iron brush so that the bond between tins and concrete became stronger [8]. The aggregate is important material to give shape to the concrete and also to reduce shrinkage. The aggregate fill $70 \%$ to $80 \%$ of the volume in concrete. In General, the aggregate size $40 \mathrm{~mm}$ are used for normal strength and $20 \mathrm{~mm}$ in size is used for high strength concrete. Table II shows the type of coarse aggregate and its size [9].

Table II: The types of coarse aggregate [9]

\begin{tabular}{cc}
\hline Coarse aggregate & Size \\
\hline Fine gravel & $4 \mathrm{~mm}-8 \mathrm{~mm}$ \\
Medium gravel & $8 \mathrm{~mm}-16 \mathrm{~mm}$ \\
Coarse gravel & $16 \mathrm{~mm}-64 \mathrm{~mm}$ \\
Cobbles & $64 \mathrm{~mm}-256 \mathrm{~mm}$ \\
\hline
\end{tabular}

Aggregate that passing sieve $4.75 \mathrm{~mm}$ are known as fine aggregate. Natural sand and clay are generally used as a fine aggregate [9].

\section{Result}

The result of compressive strength and slump test show the decreases value when the percentage used of quarry dust is more than $50 \%$. This may occur because the dust surface is rough and the more used of it more water needed. For density test, the results are differences because of the concrete mix are not compacted wisely into the moulds [3]. Concrete that mixed up with quarry dust should less the quantity of water used, because the more uses of water will decrease the compressive strength. This is happen because quarry dust can diffuse more water. $40 \%$ replacement of quarry dust gives maximum value in compressive strength compared to normal concrete but the strength will decrease when the replacement are more than 50\% [5]. While for slump test, the workability of paving blocks are decrease with the increases of size and percentage used of tin compared to control paving blocks. The concrete density that mixed up with tin is less then control paving blocks [8].

\section{Advantages}

The use of cans in
concrete may increase

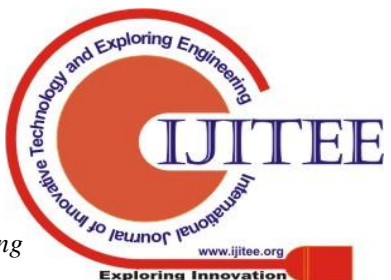


concrete mechanical properties such as compressive strengths and density and the increase used of the percentage and size of the tin in concrete will also increase the compressive strength but reduces the workability of the concrete [8]. Concrete strength depends on the bonding of fine aggregate and cement mixture to fill the voids space that caused by coarse aggregate [10].

\section{MATERIALS}

Fig. 2 shows the flow chart for the process of the work development of paving blocks.

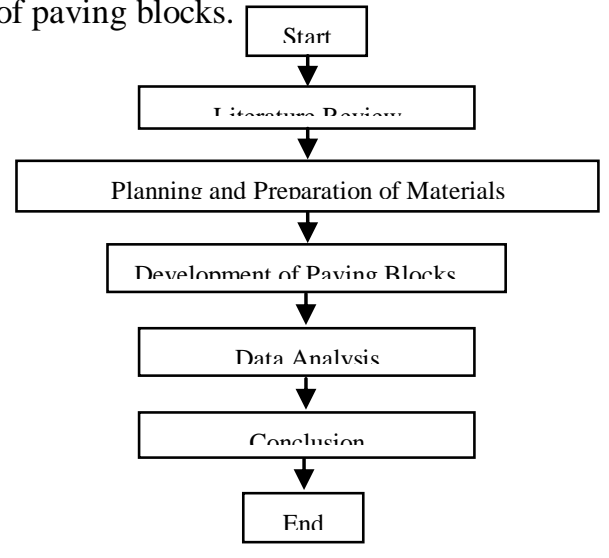

Fig. 2: Flow chart for the process of project

\section{A. Type of Materials}

For concrete work ordinary Portland cement is used which this type of binder has two important properties, which is good in adhesion and cohesion With these features, cement will act as a binder to bind the aggregate to form a strong concrete mix. Then two kinds of fine aggregate used, which is sand and quarry dust. Sand is used for control paving blocks while quarry dust is used for Eco-Friendly Paving Block. Fine aggregate that used are passing the sieve analysis test at size $2.36 \mathrm{~mm}$. For coarse aggregate, control paving blocks used coarse gravel while Eco-Friendly Paving Block use $60 \%$ of gravel stone and $40 \%$ of waste material (tin and plastic) and the coarse gravel used are passing $20 \mathrm{~mm}$ in size of sieve analysis test. The water used based on water/cement ratio to ensure the concrete mixture is not very liquid and are not out of the water. The water used must be no impurities and not oily.

To work on control paving block the ratio of materials used for cement: sand: coarse gravel is 1:2:4 and for Eco-Friendly Paving Block other ratio used that is $1: 2$ : 2.4:1.6 which it represents (cement: dust quarry: coarse gravel: tin and plastic). Volume of $0.006 \mathrm{~m} 3$ concrete mixtures are made for 6 moulds based on the ratio. Table III shows the quantity of material that used for both types of paving blocks.

Table III: Quantity of material used

\begin{tabular}{cccc}
\hline $\begin{array}{c}\text { Paving } \\
\text { blocks }\end{array}$ & Cement & $\begin{array}{c}\text { Fine } \\
\text { aggregate }\end{array}$ & $\begin{array}{c}\text { Coarse } \\
\text { aggregate }\end{array}$ \\
\hline Control & $2.24 \mathrm{~kg}$ & Sand & Coarse \\
$(1: 2: 4)$ & & $4.02 \mathrm{~kg}$ & gravel \\
& & & $8.1 \mathrm{~kg}$ \\
Eco-Friendly & $2.24 \mathrm{~kg}$ & Quarry dust & Coarse \\
Paving & & $4.02 \mathrm{~kg}$ & gravel \\
Block & & & $4.81 \mathrm{~kg}$ \\
$(1: 2: 2.4: 1.6)$ & & & Plastic + tin \\
& & & $3.2 \mathrm{~kg}$ \\
\hline
\end{tabular}

\section{B. Procedures and Testing}

There are several types of tests for concrete and a test for aggregate to get the size needed. The test for concrete are slump test, density test and cube test for compressive strength while the test for aggregate are sieve analysis test. Slump test are done to find the workability of the concrete mix. Cube test is an important test for concrete because it is carried out to determine the compressive strength of concrete to bear the maximum load. The results obtained for this test also shows the companionship of concrete mixture in producing the desired strength.

First step from the procedure are making 12 moulds with size $200 \mathrm{~mm} \times 100 \mathrm{~mm} \times 50 \mathrm{~m}$. Then, fine and coarse aggregate will be test by sieve analysis test to get the size needed. After that, the concrete work will be done and proceed with the tests. First test are slump test where the result should not exceed or less then $75 \mathrm{~mm}( \pm 25 \mathrm{~mm})$, to achieve the real slump and workability. Then it will be cube test and curing process to proceed with density test where the mass $(\mathrm{kg})$ of paving blocks will be divided by the volume $\left(\mathrm{m}^{3}\right)$ and compressive strength test where the compressive result will get when load $(\mathrm{kN})$ at the failure divided by the area of the surface paving block (m2) when achieve 7 and 14 days. Fig. 3 shows the size of mould that been used.

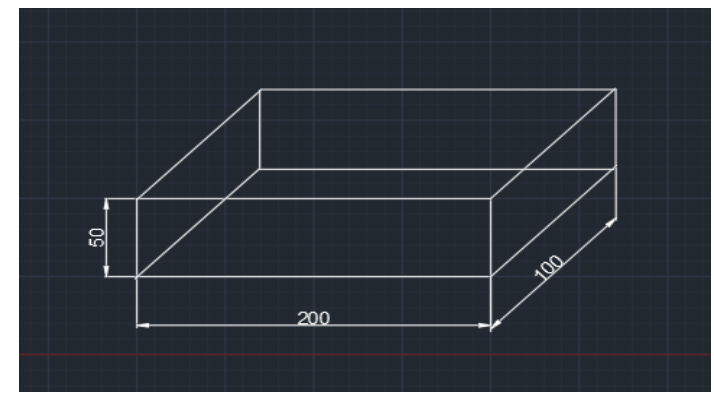

Fig. 3: The size of mould

\section{RESULTS AND DISCUSSIONS}

Table IV shows the result of the test for paving blocks and Fig. 4 and Fig. 5 
shows the graph of density test and compressive strength test.

Paragraph below explain detail about the results for each test.

Table IV: Result of the tests

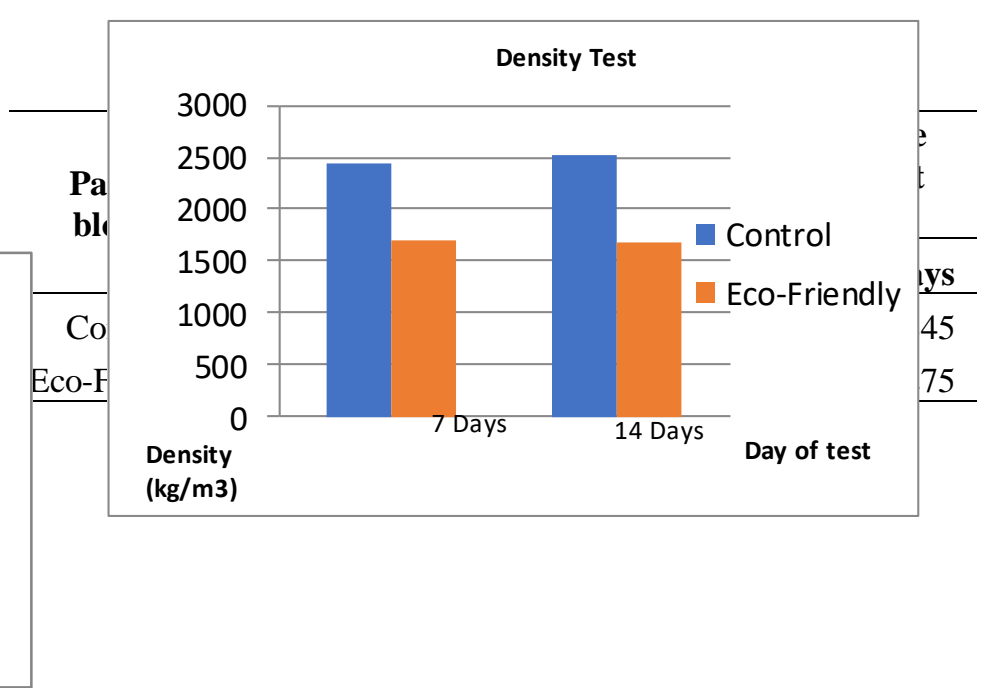

Fig. 5: Compressive strength test 
Based on the slump test result, workability control paving block is better than Eco-Friendly Paving Block which the slump of Eco-Friendly Paving Block is higher $95 \mathrm{~mm}( \pm$ $25 \mathrm{~mm}$ ) compared to control paving blocks which the reading are $70 \mathrm{~mm}( \pm 25 \mathrm{~mm})$. But both paving blocks still in the real slump phase. Workability of Eco-Friendly Paving Block is low may be caused by the use of tin with large size $3 / 2$ "and the percentage of its use with plastic is also a higher which is $40 \%$.According to past research, workability of slump test will decrease with the increases in size and the percentage use of tin compared to control cube [8]. Other than that, past researcher also found the uses of quarry dust that excess of $50 \%$ also will lower the workability which increased the reading of slump test [10].

Based on the density test result, can be concluded that Eco-Friendly Paving Block are lighter than control paving block. Therefore, the objective to prove the Eco-Friendly Paving Block was lighter than control paving block was achieved based on the result and analysis.

Based on Table IV, the compressive strength result on day 7 for Eco-Friendly Paving Block reached higher value compared to control paving blocks. While the testing for 14 days shows the results of compressive strength for control paving blocks are better than Eco-Friendly Paving Block. According to the past research this may happen because the water is easily diffuse into the quarry dust than sand [5]. Therefore, from the curing process Eco-Friendly Paving Block will diffuse more water with the increases of days. For this study, $100 \%$ of quarry dust was used for Eco-Friendly Paving Block which will lower the compressive strength. Ashish and Hardik said, the replacement of the $40 \%$ quarry dust give maximum results in strength compared to normal concrete and strength would decrease when the replacement is exceed more than 50\% [5]. Meanwhile Uroosa et. al found that, tins with many scratching can strengthen the bond between tin and concrete mixture [8].Therefore, it can be analyzed that tins used in this mixture are less scratching and not bond well with cement and cause a lot of voids. From the result of compressive strength of Eco-Friendly Paving Block can be used in areas where there are less traffic flow such as garden, playground and walkway. So, the objective of this study are still achieve where the result are $13.33 \mathrm{~N} / \mathrm{mm} 2$ which is in range of grade $\mathrm{C}$ (walkway) and receive higher result from the average of grade D (garden and playground).

\section{A. Related to Problems}

Control paving blocks has some flaws such as the manufacturing require high cost material, and this paving also heavier. Therefore Eco-Friendly Paving Block are produced to reduce costs with the use of waste materials as replacement of aggregates and the waste materials also lighter than coarse gravel once that used as aggregate.

\section{CONCLUSIONS}

Based on the result and analysis that have be done, workability of control paving blocks are better than Eco-Friendly Paving Block although these two type of paving are in real slump phase. For density, Eco-Friendly Paving Block result are more better than control paving block and this show Eco-Friendly Paving Block are less density and more lighter than control paving blocks. Compressive strength for Eco-Friendly Paving Block decrease with days compared to control paving blocks where the result are increase. For the conclusion, the aim and objectives of these study are achieve where the waste material can be used as aggregate in concrete paving blocks but used in little percentage. This also can protect our environment from the waste material that can ruin the ecosystem. The objective also achieve where the cost for making Eco-Friendly Paving Block also cheaper because the used of waste material in the mixture. The advantages of light paving blocks will easier the installation work. Lastly, although the result of compressive strength are decrease for Eco-Friendly Paving Block compared to control paving blocks, but from the result this research still follow the scope of work where the Eco-Friendly Paving Block are suitable to use at less and non-traffic area.

For the next research, the recommendations of the study are use the gravel that pass $10 \mathrm{~mm}$ sieve analysis test because paving blocks are small based on their shape. Besides that, the used of quarry dust must not exceed $50 \%$ to achieve higher result in compressive strength and it can be made for a few ratio or percentage such as $10 \%, 20 \%$ and $30 \%$. Then, use a smaller size of tin so that a mixture of tin and concrete could bond and reduces voids and space. Next, use some percentage of tin and plastic for the research and study to compare the strongest paving blocks based on the percentage used of tin and plastic. Lastly, the highest grade of concrete can also be used to strength the blocks.

\section{ACKNOWLEDGMENT}

This study was sponsored by the Ministry of Education Malaysia through FRGS grant (Vot No.:1620). The author would like to thank to Research Management Centre (RMC), UTHM, Johor. The extended gratitude to Rabiyatuadaviah Mohamed Muhamad Afiq Zamri and Muhamad Hazim Nasrullah Mohd Idrus for accomplished this study.

\section{REFERENCES}

1. Koli Nishikant, Aiwale Nachiket, Inamdar Avadhut, Abhishek Sangar, "Manufacturing of concrete paving block by using waste glass material", International Journal of Scientific and Research Publications Volume 6, issue 6, 61, June 2016.

2. Kevin Klarens, Michael Indranata, Luthfi Al Jamali, and Djwantoro Hardjito, "The use of bottom ash for replacing fine aggregate in concrete paving blocks", Matec Web of conferences 138, 01005, 2017.

3. Radhikesh P. Nanda, Amiya K. Das, Moharana.n.c, " Stone crusher dust as a fine aggregate in concrete for paving blocks", International Journal of Civil and Structural Engineering, Volume 1, No 3, 2010.

4. Muhammad Fauzi Mohd. Zain, Sudharshan Naidu Raman, Azimin Samsul Tazilan, Abdul Halim Ismail, Mazlan Tahir dan Zulhairuse Md Darus, "Penggantian sebahagian pasir dengan debu kuari ke atas ciri konkrit prestasi tinggi baru", Jurnal Kejuruteraan 17 page 3-12, 2005.

5. Ashish Patanwadia, Hardik Solanki, "Effect of replacement of natural sand by quarry dust on mechanical Properties", Volume5, issue 4, International Journal of engineering technology science and research, April 2018.

6. Anzar Hamid Mir, March, "Improved concrete properties using quarry dust as replacement for natural Sand", International Journal of engineering research and development, Volume 11, issue 03 , pp.46-52, 2015. 


\section{Development of Paving Blocks Using Waste Materials}

7. B. Shanmugavalli, "Reuse of plastic waste in paver blocks", International Research Journal of Engineering and Technology (irjet), Vol. 6 issue 02, February 2017.

8. Uroosa Iqbal, Muhammad Akram, Abdullah Saand, "Soft drink tins as fibre reinforcement in concrete", Proceedings of Ampe, 14-15, 2015.

9. M. Achitra, R. Ambika Rajasree, R. Vijayalakshmi Pandit, V.Saranya, "Recycled Plastic and Coconut fibre used in concrete paver block", Volume 8 issue no.4 Research Article, 2018.

10. Naushad Khan, Ruchi Chandrakar, "An experimental study on uses of quarry dust to replace sand in concrete", International research journal of engineering and technology Volume: 04 issue: 11, Nov 2017.

\section{AUTHORS PROFILE}

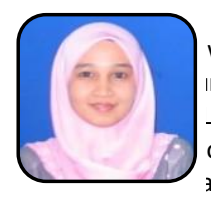

Nor Baizura Hamid is a Bachelor holder in Civil with Honors which was graduated in 2009 from In Hussein Onn Malaysia. She is currently a Civil -ecturer in UTHM with 8 years experience. She has ore than 20 articles in journals and conference as main author and co-author for the last 5 years. Of SCOPUS indexed articles. She has been also involved in hes starting from 2013 until now. She has involved in 11 Its as main- and co-researcher, funded by the Universiti Onn Malaysia (UTHM) and Malaysian Ministry of רe also a Graduate member of Malaysian Board of BEM) from 2011. She is currently holding a post as gineer in UTHM and keeps on fully dedicating in arvising, research and publication for the sake of current neration.

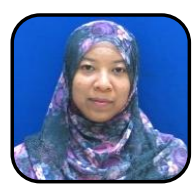

Siti Noraiza Ab Razak received he PhD. in Science (Physics) majoring in Laser Application Technologies, graduated from Universiti Teknologi Malaysia (UTM) in 2015. Currently work as a Physics lecturer in Centre for Diploma Studies, Universiti Tun Hussein Onn Malaysia (UTHM). She received her MSc Science (Physics) in 2011 and Bachelor of Science (Health Physics) in 2009 from UTM. She is also acts as an Associate Researcher at Microelectronics and Nanotechnology-Shamsuddin Research Centre (MiNT-SRC) UTHM and have been actively involved in research since 2011 as Research Assistant and been involved as committee member for International Laser Technology \& Optic Symposium LATOS in 2014. Her areas of research interest covers various field such as laser applications, material science (thin films), nanomaterials, and green energy technology. Currently involved with several grant projects under the university sponsorship and MOE as the head of researcher and also co-researcher, mainly focus on green energy technologies. Apart from teaching, she is also committed in journal paper and book chapters writing, and has been published in Scopus Indexed Journal, WOS, and proceeding articles

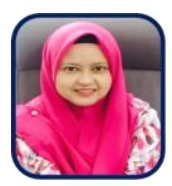

Mardiha Mokhtar is a Masters holder in Civi Engineering graduated from Universiti Tun Hussein Onn Malaysia (UTHM) in 2011. Her field of specialty is Geotechnical Engineering. She was a Civil Engineer at Public Works Department and in 2013, she joined the UTHM as a Lecturer. Since 2012 she has been involved in publication of more than 20 journals and proceeding articles, books and book chapters as main and co-authors and been awarded as Outstanding Paper Award by Academic Research Society of Malaysia in 2018. Since 2015, she has involved in 4 research grants as main and co-researcher, funded by the Universiti Tun Hussein Onn Malaysia (UTHM). Her current research interests include soil stabilization, coastal erosion and UAV applications. Her teaching topic involved Geotechnical Engineering, Drawing Engineering, Static and Dynamic, Mechanics of Materials and Construction Engineering. She is currently a Lecturer in UTHM and associate researcher at Centre of Applied Geomatics for Disaster Prevention (CAGeD), Faculty of Civil and
Environmental Engineering, UTHM.

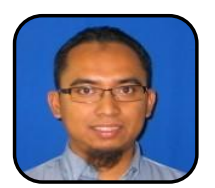

Mohd Erwan Sanik is a Masters holder in Civil Engineering, specialty in Highway and Traffic Engineering. He graduated from Universiti Sains Malaysia in the year 2000 (Bachelor of Engineering) and 2007 (Master of Science). Since 2007, he has been involved in publication of more than 35 journal and proceeding articles, books and book chapters as main- and co-authors in various Civil Engineering areas. Of these, 17 are SCOPUS indexed articles. He has been also involved in many researches starting from 2003 (as research officer) until now. Since 2009, he has involved in 21 research grants as main- and co-researcher, funded by the Universiti Tun Hussein Onn Malaysia (UTHM) and Malaysian Ministry of Education. He is a Graduate member of Malaysian Board of Engineering (BEM), Malaysian Board of Technologies (MBOT), and Road Engineering Association of Malaysia (REAM). Membership in REAM made him automatically also a member of the Road Engineering Association of Asia and Australasia (REAAA). He is recognized as a Professional Technologist (Ts) from MBOT since 2018 under the field of Transportation and Logistics Technology. He is currently holding a post as Industrial Fellow in UTHM and keep on fully dedicating in teaching, supervising, research and publication for the sake of current and future generation.

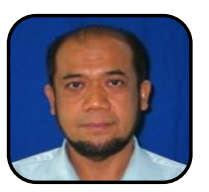

Masiri Kaamin is a Masters holder in Land Surveying (Geomatics), specialty in Geographic Information System. He graduated from Universiti Teknologi Malaysia in the year 1989 (Bachelor of Surveying) and 2001 (Master of Science). Since 2001, he has been involved in publication of more than 80 journals and proceeding articles, books and book chapters as main- and co-authors in various Geomatics and Civil Engineering areas. Of these, 42 are SCOPUS indexed articles. He has been also involved in 25 research grants as main- and co-researcher, funded by the Universiti Tun Hussein Onn Malaysia (UTHM) and Malaysian Ministry of Education. He is a Graduate member of Malaysian Board of Technologies (MBOT). He is recognized as a Professional Technologist (Ts) from MBOT since 2018 under the field of Resource Based, Survey \& Geomatics Technology. He is currently holding a post as Associate Professor in UTHM and keep on fully dedicating in teaching, supervising, research and publication for the sake of current and future generation. 
Ahmad Hakimi Mat Nor is a Masters holder in Civil Engineering, specialty in Geotechnical Engineering on soft soil. He graduated from Universiti Tun Hussein Onn Malaysia in the year 2008 (Bachelor of Civi Engineering) and 2012 (Master of Civil Engineering). Since 2014, he has been involved in publication of more than 25 journal and proceeding articles, books and book chapters as main- and co-authors in various Civil Engineering areas. Of these, 6 are SCOPUS indexed articles. He has been also involved in many researches starting from 2009 (as instructor engineer) until now. Since 2009, he has involve in 8 research grants as main- and co-researcher, funded by the Universiti Tun Hussein Onn Malaysia (UTHM). He is a Graduate member of Malaysian Board of Engineering (BEM), and Malaysian Board of Technologies (MBOT) $\mathrm{He}$ is currently holding a post as Industrial Fellow in UTHM and keep on fully dedicating in teaching, supervising, research and publication for the sake of current and future generation.

Mohd Zakwan Ramli is a Masters holder in Civi Engineering which was graduated in 2011 and his forte is Highway \& Transportation Engineering. He obtained his Bachelor of Civil Engineering with Honors degree from Universiti Tun Hussein Onn Malaysia in 2009. He is currently a Civil Engineering Lecturer in Universiti Tenaga Nasional which in the field of Project Management and Highway Engineering. He has published more than 30 articles in journals and conference proceedings as main author and co-author for the last 5 years. He leads few research grants with more than RM 700,000 in total for the past 2 years. His first research grant was pedestrian dynamic behavior in railway stations. While, the main current research grant is related to construction management for power plant construction projects in Malaysia which was granted by Tenaga Nasional Berhad. He also involved as a project member in a consultation project related to fluid-structure interaction study at hydro power dam structure. He was registered as a Graduate Member with Board of Engineers Malaysia (BEM) in 2011. He also registered in National Industrial Experts Directory (majoring in Construction) under the administration of Skills Development Department. He was accredited as one of National Occupational Skills Standard Panel in 2016 under the Ministry of Human Resource Malaysia (for Road Construction). 